\title{
Graciano, um imperador niceno e santo: uma identidade construída nos documentos de Ambrósio, bispo de Milão
}

\author{
Gratian, a Nicene and holy emperor: an identity built on the texts \\ of Ambrose, bishop of Milan
}

\author{
Janira Feliciano Pohlmann*
}

Resumo: O objetivo deste artigo é analisar alguns elementos edificados por Ambrósio, bispo de Milão, para formatar uma identidade cristã baseada no Concílio de Niceia de 325, e, ao mesmo tempo, identificar Graciano como um "santo imperador" defensor da fé professada pelo sacerdote milanês. Para alcançar este objetivo e comprovar minhas hipóteses, examino duas obras tratadísticas de Ambrósio: De fide e De Spiritu Sancto. Observo que ambas as obras foram escritas entre 378/380?-383, por solicitação do Augusto Graciano. Era, portanto, um momento em que o credo de Niceia afirmava sua noção de ortodoxia e a natureza divina do imperador romano ganhava aspectos cristãos.

Abstract: The purpose of this article is to analyze some elements built by Ambrose, bishop of Milan, to create a Christian identity based on the Council of Nicaea of 325, and at the same time identify Gratian as a "holy emperor" defender of this faith. To achieve this objective and to prove my hypothesis I analyze two works: De fide and De Spiritu Sancto. I note that both works were written by Ambrose between 378/380?-383 AD at the request of Augustus Gratian. It was a moment in which the Niceism asserted its notion of orthodoxy and the divine nature of the Roman emperor gained Christian aspects.

\author{
Palavras-chave: \\ Imperador Graciano. \\ Ambrósio de Milão. \\ Identidades. \\ Concílio de Niceia. \\ Ortodoxia.
}

\section{Keywords: Emperor Gratian. Ambrose of Milan. Identitys. Council of Nicaea. Orthodoxy.}

\footnotetext{
* Pós-doutoranda em História pela Universidade Estadual Paulista, campus Franca. Bolsista da Fundação de Amparo à Pesquisa do Estado de São Paulo (Fapesp), no Brasil (processo 2016/20942-9), e no Exterior (Espanha - BEPE 2017/269392; Itália - BEPE 2018/03187-8).
} 


\section{Introdução}

m um mundo "globalizado", no qual todos podemos usar a mesma marca de roupa norte-americana produzida na China, práticas cotidianas e elaborações discursivas que tendem ao universalismo reduzem as diferenças individuais para se sobressaírem. A retórica utilizada por líderes detentores de poderes diversos (políticos, midiáticos, etc.) organizam discursos que alimentam uma política construtora de verdades e valores apresentados como universais (WALLERSTEIN, 2007, p. 26). Baseados nestas argumentações - por vezes impostas à força, por vezes aceitas como o único caminho correto -, pequenos grupos, comunidades e países inteiros frequentemente abrem mão de uma identidade para aderir à outra que, ao passo que agrega pessoas, exclui cada vez mais as diferenças.

Para se contrapor a este cenário entendido como universal, que ressalta a unidade e diminui as especificidades, os estudos sobre "identidades" vêm ganhando espaço e destacam diversidades culturais, sociais, políticas e religiosas. Observo que trato aqui de identidades, no plural. A respeito do conceito de identidade, comparto a assertiva do sociólogo e filósofo Zygmunt Bauman (2005, p. 17), para quem "o 'pertencimento' e a 'identidade' não têm a solidez de uma rocha [...], são bastante negociáveis e revogáveis". Ou seja, entendo que "sentimentos de pertença" e "identidades" são elaborações que surgem a partir de discursos organizados dentro de um contexto sociopolítico múltiplo e são sustentados ou rechaçados conforme decisões dos grupos mais fortes de uma comunidade. É assim ainda hoje, foi assim durante a Antiguidade romana.

Nesta conjuntura, noto que as identidades não são naturais. São, sim, elaborações discursivas constantemente reformuladas dentro de contextos históricos. É certo que, quando comparadas aos modelos universalizantes, estas identidades marcam algumas particularidades. Entretanto, os esquemas identitários precisam excluir as diferenças existentes dentro do grupo identificado para fornecer uma noção de coesão e de pertencimento. Então, por mais que ideias tendentes ao universalismo, à unidade e à naturalização - como "a cidade romana", "a religião romana", "o povo romano", entre outras - tenham sido abandonadas pelos estudiosos atuais, entendo que uma identidade ainda carrega em si noções e valores que deveriam ser considerados universais em determinado contexto e espaço histórico, dentro de um grupo. As várias identidades, sim, formam "determinada cidade romana", "uma religião romana específica de um tempo e espaço" e assim por diante.

No caso analisado neste artigo, verifico alguns elementos edificados por Ambrósio, bispo de Milão (374-397), para formatar uma identidade cristã baseada no credo niceno 
de 325 e, ao mesmo tempo, identificar Graciano como um "santo imperador" defensor da fé professada pelo sacerdote milanês. Esta identidade sociopolítica, religiosa e cultural elaborada e sustentada pelo bispo foi um dos componentes dos discursos que legitimaram o poder imperial e a tentativa de Ambrósio de adornar o cristianismo niceno com o manto da ortodoxia.

Devido à expansão de seus territórios e à diversificação de suas relações sociais, os romanos tiveram que adaptar suas identidades e auto-entendimentos para um mundo social, cultural e político que se dilatava (PERKINS, 2009, p. 1). Em específico, percebo que a identidade cristã erigida por Ambrósio foi organizada em um contexto em que várias comunidades cristãs requeriam para si a qualificação de "cristianismo verdadeiro", ortodoxo. Em Milão, cidade em que Ambrósio exercia seu episcopado, dois grupos se destacavam nesta querela: os nicenos, seguidores dos dogmas cristãos elaborados no Concílio de Niceia de 325; e os arianos, que professavam as crenças cristãs que começaram a ser propagadas pelo presbítero Ário de Alexandria, na primeira metade do século IV.

É necessário esclarecer que, no contexto ambrosiano, ainda não havia uma religião tida como ortodoxa. Havia, sim, muitos debates e inúmeros concílios foram realizados em torno desta questão.

A palavra "ortodoxia", de origem grega, reconheceria uma doutrina como verdadeira. Para Platão (Crátilo, 420a-b; 412a; 437a-b; Gorgias, 454d; A República, VII, 533534), a dóxa referia-se à emissão de uma opinião pensada, sendo assim, estava vinculada a uma ação humana e à persuasão (díoxis) - um dos elementos da retórica -, e, também, à crença (oíesis), pois manifestava a preparação da alma acerca das coisas. Durante a Antiguidade, os líderes de diferentes comunidades cristãs edificaram discursos com o intuito de manejar a opinião (dóxa) e apreender seguidores - Ambrósio era um destes líderes religiosos. Aqueles que eram persuadidos por tais crenças defendiam-na como correta e exata (orthós). Nos ambientes nos quais aqueles discursos eram acatados, a exatidão (orthós) passava a adjetivar a apreciação (dóxa). Em determinados espaços e em momentos específicos, portanto, a orto-doxia ganhava o estatuto de opinião verdadeira. Assim, a ortodoxia carregava consigo julgamentos de grupos específicos.

No século IV, observo que, alcançar o estatuto de uma religião ortodoxa, era um anseio de muitas comunidades religiosas. Todavia, este estatuto era provisório, uma vez que era transformado segundo a influência dos bispos nos círculos de poderes imperiais e/ou a crença defendida pela figura imperial. Os imperadores Constâncio II e Valente, favoráveis ao arianismo, por exemplo, puniram com o exílio Atanásio e Hilário de Poitiers, defensores dos princípios nicenos. Já o imperador Graciano solicitou a Ambrósio duas obras que esclarecem os dogmas nicenos (De fide e De Spiritu Sancto); situação que 
forneceu ao bispo e à crença nicena um espaço de destaque na comunidade milanesa. Não é possivel, portanto, tratar de uma ortodoxia consolidada no contexto ambrosiano.

Pesquiso, então, de que maneira o sacerdote milanês criou e sustentou a imagem de um "santo imperador" para Graciano (367-383) e a forma como esta identidade imperial ajudou a requerer para a fé cristo-nicena a força de uma crença ortodoxa. Uma ortodoxia provisória naquele momento; criada, é claro, pouco a pouco, durante o processo histórico. E que teve em Ambrósio, um dos seus pilares.

Para tanto, analiso dois documentos de autoria de Ambrósio e que são do gênero tratadístico: Sobre a fé (De fide) e Sobre o Espírito Santo (De Spiritu Sancto). Ambas as obras foram escritas entre $378 / 380$ ? e 383 e são frutos de solicitações imperiais de Graciano para Ambrósio para que o bispo elucidasse os princípios da crença religiosa defendida por ele e formatada conforme o Concílio de Niceia de 325.

O objetivo principal destes livros era a defesa da crença cristã-nicena em um contexto em que conviviam dentro do Império Romano várias crenças cristãs (priscilianos, arianos, nicenos, etc.). Entre estas crenças, destaco a força do arianismo que, no norte da Itália - terra de Ambrósio - recebia o apoio de Justina, mãe do imperador Valentiniano II (375-392), aquele com quem Graciano compartilhou o poder de império no Ocidente entre os anos de 375 e 383. Mesmo com foco na construção de uma ortodoxia nicena, ao explicar ao imperador e a seu público, a unidade da Trindade expressa no sínodo niceno, o bispo de Milão ressaltou os atributos de Graciano como um governante cristão e santo, por isso, apropriado para conduzir os romanos - isso, obviamente, conforme os preceitos ambrosianos. Nestas obras, portanto, Ambrósio criou uma identidade nicena que deveria ser considerada exata, correta, ou seja, ortodoxa e, simultaneamente, construiu a imagem de um imperador que aceitava e, acima de tudo, defendia tal noção. Trato, então, de uma idealização, é fato, mas também de um discurso que respondia ao desejo de Graciano e de um grupo importante da comunidade milanesa: os nicenos.

\section{Contra quem lutar?}

Ambrósio (De fide, I, Prologus, 3) destacou que, pouco antes de sair em combate, Graciano havia pedido para que o bispo escrevesse sobre sua fé. $O$ autor ainda esclareceu que o inimigo estrangeiro que Graciano enfrentava eram as tribos godas (De fide, II, 16, 137-138). A argumentação do bispo milanês, então, construía para o Augusto uma imagem de um líder que cuidava tanto dos perigos externos como dos assuntos de fé, que, naquele momento, dividiam os milaneses em diferentes comunidades religiosas. 
Estas comunidades elaboravam para si discursos que nutriam sua ortodoxia, ou seja, sua noção de ser "a verdadeira e correta crença", enquanto excluíam de seus grupos aqueles que discordavam de seus princípios. O historiador Neil McLynn (2009, p. 262) sugere que Ambrósio erigiu, em Milão, uma comunidade religiosa afiançada por Graciano e sua corte. Certamente, a mudança de Graciano e de sua corte de Tréveris para Milão, no ano de 381, possibilitou a aproximação entre o sacerdote e o imperador, situação que promoveu a autoridade de Ambrósio e lhe ofereceu voz para anunciar suas ideias. Ao passo que o bispo ajudou a validar a utilidade pública de Graciano como um comandante necessário para os romanos.

Visto que os tratados ambrosianos foram escritos entre 378/380? e 383, analiso um contexto em que estas obras alimentavam a diferenciação e a anunciação dos termos "católico" e "herético". As constituições do Código Teodosiano, organizadas sob o título De haereticis (C.Th., XVI, 5), ajudaram a consagrar esta distinção. Entre as constituições ali recolhidas, destaco a constituição XVI, 1, 2 do Código Teodosiano, datada do ano 380, conhecida como Edito de Tessalônica e assinada por Teodósio. Nela, os termos "católico" e "herético" foram definidos legalmente. De acordo com esta norma, os seguidores do credo niceno, propagado pelo "divino apóstolo Pedro" (divinum petrum apostolum), seriam chamados "cristãos católicos" (christianorum catholicorum), ou seja, cristãos universais. Aqueles que se contrapunham a estes preceitos e professavam "dogmas infames" (dogmatis infamiam) seriam denominados "heréticos" (haeretici) (C.Th., XVI, 1, 2; 2, 1).

Certamente, estas definições tinham a aprovação de Ambrósio, to davia a historiadora Rita Lizzi Testa (2011, p. 467) ressalta "o valor geograficamente limitado da maior parte das disposições imperiais". A autora sustenta que, longe de impor a submissão de todo o Império a uma fé definitiva por meio de uma lei, o Edito de Tessalônica estava voltado ao povo de Constantinopla e era uma medida de Teodósio para restabelecer a ordem na capital oriental após a morte do imperador Valente, adepto da fé cristã-ariana (TESTA, 2011, p. 473-474; 1996, p. 339).

Se, por um lado, portanto, os textos legislativos ajudaram a diferenciar "católicos" e "heréticos", por outro lado, ressalto que eles tinham alcance restrito. Por isso, é significativo que seus contextos de produção e os destinatários destas constituições sejam examinados. Tendo em mente o alcance limitado dos textos legislativos, destaco a importância de outras elaborações discursivas que alimentaram a distinção entre "católicos" e "heréticos" e ampararam a noção da ortodoxia nicena. Nesta conjuntura, a denominação de Caroline Humfress (2007) sobre os termos "católico" e "herético" é expressiva. A autora os considera como "conceitos performáticos", ou seja, vinculados às regras sociais que os definiam (HUMFRESS, 2007, p. 220). Sendo assim, retomo a necessidade da negociação e a falta de 
solidez destes conceitos, como afirmou Bauman (2005) com relação à "identidade". Estes elementos, portanto, se complementam em meu trabalho e me oferecem caminhos para estudar algumas elaborações ambrosianas que buscavam fornecer o critério de verdade ao credo niceno e legitimar a figura imperial de Graciano.

Trato de argumentações restritas a grupos específicos. No caso de Ambrósio, percebo sua influência em comunidades do norte da Itália, onde o bispo milanês conseguiu angariar sedes episcopais para seus escolhidos. Minhas análises de forma alguma consideram uma hegemonia do pensamento ambrosiano no Ocidente romano. Observo, sim, a necessidade contínua deste bispo de se fazer ouvir e ser entendido entre aqueles que o cercavam. Noto, ainda, um sacerdote que aproveitou uma solicitação imperial para defender sua crença religiosa e criar para ela um imperador ideal: cristão-niceno e santo.

Em seus escritos, Ambrósio explicava, ensinava e defendia os dogmas nicenos, ao passo que atacava a "ímpia heresia dos arianos" (impia arianorum haeresias), como categorizou o próprio bispo no primeiro livro de seu tratado De fide (l, 10). Este autor utilizou o termo "heresia" para excluir os arianos do grupo dos cristãos e, ainda, qualificou-os como "ímpios". Recordo que esta obra começou a ser escrita entre 378 e 380, portanto, no contexto de promulgação das constituições contra seitas heréticas. Estas disposições jurídicas atendiam a demandas sociopolíticas e não criavam ideias ou conceitos - fato que não difere de nossa situação atual. A historiadora María Victoria Escribano Paño (2014, p. 62) afirma que as leis compiladas no título $V$, do livro XVI, do Código Teodosiano, e promulgadas sob a domus teodosiana, atenderam a requerimentos de bispos e funcionários para legislar contra grupos heréticos. Ao argumento da autora, acrescento o critério da regionalidade: eram questões específicas, abordadas por líderes cristãos que não compartilhavam os mesmos dogmas de fé. Ressalto que, quer fossem nas constituições do Código Teodosiano, quer fossem nos textos de escritores cristãos nicenos, na época de Ambrósio, os termos "católico" e "herético" e suas respectivas cargas positiva e negativa faziam parte do linguajar daquela sociedade.

É possível notar um estreito relacionamento entre Graciano e Ambrósio devido aos textos que o bispo dedicou ao Augusto, inclusive as cartas escritas para este governante, e, também, devido à carta redigida pelo próprio imperador a Ambrósio. O tratado De fide, observo, foi escrito em duas etapas. Em um primeiro momento, Ambrósio escreveu e encaminhou a Graciano apenas dois livros. Após Graciano trasladar a corte imperial de Tréveris para Milão, o governante aproximou-se ainda mais do sacerdote milanês e solicitou que ele continuasse a redação do tratado, o que resultou em outros três livros. O bispo registrou tal pedido no início de seu livro III: 
Como metinhas encomendado, clementíssimo imperador, que escrevesse algumas coisas sobre a fé (de fide) para te instruir e tu mesmo havias me encorajado, frente à minha indecisão e como me encontrava assediado em tempo de guerra, escrevi apenas dois livros [...] De outra parte, a piedosa preocupação de tua clemência, me convida a completar o que resta. (Amb., De fide, III, 1-2).

Neste excerto, o autor destacou que escrevia "sobre a fé" ao ser solicitado e encorajado por Graciano. Em primeiro lugar, noto que Ambrósio registrou que trataria "sobre a fé". Não especificou que seria sobre a fé nicena, pois, para ele, esta era a única fé verdadeira, logo, não se faziam necessários outros esclarecimentos. Escribano Paño (2009, p. 39) alega que o livro XVI do Código Teodosiano - aquele que contém entre suas constituições o Edito de Tessalônica - é um compêndio de regras religiosas promulgadas desde Constantino até Teodósio II, que testemunha o processo de identificação entre cristianismo e sociedade. Em especial, o título V (De haereticis) revela a exclusão social disseminada a partir do credo niceno e ajuda a criar uma identidade cristã baseada neste dogma. Destaco que esta identificação foi um processo construído pouco a pouco por meio de leis, textos literários e pregações realizadas por líderes religiosos.

Toda a fé proclamada nos textos ambrosianos tinha como alicerce o dogma niceno, anunciador da Trindade Divina. Por isso, percebo nas obras deste sacerdote mais uma argumentação que conferia a noção de ortodoxia à crença nicena e que, consequentemente, identificava os seguidores do credo niceno como os únicos cristãos. Estas construções retóricas nutriam novas normas em defesa desta fé e, em contrapartida, aqueles que não se ajustavam a tais normas deveriam ser eliminados do corpo social de determinadas comunidades, como as de Milão e de Constantinopla.

Em segundo lugar, no trecho evidenciado anteriormente é possível ler o requerimento imperial feito por Graciano a Ambrósio. Esta solicitação dava ao sacerdote o aval para falar em nome do soberano. De acordo com a afirmação da historiadora Averil Cameron (1991, p. 1), as sociedades possuem discursos fornecedores de poder social. O discurso ambrosiano colocou o bispo ao lado do Augusto, pois o governante teria encorajado Ambrósio a redigir seu tratado. Além disso, o sacerdote tinha a oportunidade de aclarar os princípios de sua fé devido a um pedido imperial. Tais elaborações ofereciam ao bispo o poder da fala e, com isso, um espaço importante para a disseminação de seus ideais. Desta forma, legitimavam-se as argumentações presentes nos dois primeiros livros do De fide e, consequentemente, aquelas alegações proporcionavam ao credo de Niceia a alcunha de fé ortodoxa, identificando esta crença como legítima e seus seguidores como católicos e verdadeiros fiéis. 
Quanto à ameaça goda citada por Ambrósio nos livros I e ll e reiterada em seu livro III quando afirmou que ele havia estado "assediado em tempo de guerra" (Amb., De fide III, 1), o historiador Guy Halsall (2012, p. 148) afirma que as fontes imperiais do século III. testemunharam por primeira vez a presença goda ao norte do Danúbio.

É possível que Amiano Marcelino tenha ressaltado a ameaça goda desde a III centúria. Entretanto, os treze primeiros livros de sua Res Gestae, que compreendiam o espaço temporal entre os anos 96 e 353, foram perdidos. Os godos, então, foram trazidos em seu livro XXII como gente "enganadora e pérfida" ("fallaces et perfidos") com a qual o Augusto Juliano (360-363) teve de lidar a fim de proteger as províncias romanas (Am. Mar., Res Gestae, XXII, 7, 8).

Amiano (Res Gestae, XXVII, 4, 1) afirmou que, no ano de 365 , os godos apoiaram Procópio em sua tentativa de usurpar o poder de império de Valente (364-378), Augusto dos territórios romano-orientais, tio de Graciano e imperador ao lado do próprio Graciano e de Valentiniano I (364-375), estes, governantes no Ocidente romano. E, no ano de 376, quando Graciano compartilhava com o jovem Valentiniano II o poder de império sobre as terras ocidentais, os godos entraram nas fronteiras imperiais ao atravessarem o Danúbio. Portanto, em época ambrosiana, os godos foram ameaças combatidas pelos três representantes da dinastia valentiniana. Este foi o inimigo externo nomeado por Ambrósio em seu tratado De fide. Como comandante militar, era contra este inimigo que Graciano impunha suas forças.

Foi neste contexto de ameaças externas aos romanos, promovidas especialmente por tribos godas, e de uma comunidade ariana forte no norte da Itália, que Ambrósio redigiu as obras examinadas neste artigo e elaborou para Graciano a imagem de um "santo imperador". Um governante que, conforme as elaborações ambrosianas, mesmo imerso em um cenário de guerra, mostrou seu interesse pela crença nicena. Edificando a imagem de um Augusto habilidoso na guerra e zeloso nos assuntos religiosos, os escritos do sacerdote milanês ajudaram a legitimar a utilidade pública de Graciano frente a seus súditos, aos seus inimigos externos, e, especialmente, frente àqueles com quem este Augusto compartilhava o poder de império e frente aos possíveis usurpadores de seu poder.

\section{Graciano: um "santo imperador" para a fé ortodoxa de Ambrósio}

Ambrósio elucidou que a santidade estava infundida em Graciano, por isso o governante não precisava aprender a respeito da fé: 
infundida. Assim, guarda os dons divinos. Pois o que ninguém te ensinou, certamente te infundiu Deus, que é o autor (Amb., De fide, I, Prologus, 2).

Com esta elaboração retórica, o bispo iniciou seu discurso para fazer do imperador um guardião da fé nicena. Percebo que o título de Augusto que o imperador portava não foi abandonado. À esta titulação, porém, acrescentou-se o benefício da santificação. Conforme este texto, Deus havia escolhido Graciano para ser líder dos romanos e para conservar a crença nicena entre os seus súditos. Nesta circunstância, não houve nenhuma inovação no discurso ambrosiano. O bispo seguiu um modelo literário cristão iniciado em época constantiniana com Eusébio de Cesareia: o envio do imperador pela providência divina. Ambrósio, portanto, estava integrado a uma tradição cristã que elaborava e difundia atributos cristãos vinculados ao detentor do poder de império.

Durante o século IV, a tradicional natureza divina imperial adquiriu novos significados no momento em que o cristianismo estabelecia suas bases como uma das religiões oficialmente aceitas do Império - com oficial, entretanto, não quero dizer que esta foi a única religião professada a partir de então; noto, por exemplo, a defesa dos antigos cultos greco-romanos por parte do senador neoplatônico Quinto Aurélio Símaco Eusébio, prefeito da cidade de Roma entre os anos 384-385. Era inegável o apoio imperial concedido por Graciano, Teodósio e, posteriormente, por Valentiniano II ao cristianismo niceno em determinadas regiões.

O classicista Giorgio Bonamente (2014, p. 18) afirma que a sacralidade do imperador não podia ser abandonada pelo cristianismo, por isso esta crença a guardou dentro de sua doutrina e gerou um novo equilíbrio entre o poder imperial e as autoridades eclesiásticas. Em seu trabalho, Bonamente alude à apoteose imperial de Teodósio, louvada por Ambrósio na oração De obitu Teodosii. Naquele momento, o bispo argumentou que o governante subira ao paraíso cristão, portanto não ascenderia à tradicional esfera destinada ao divi (BONAMENTE, 2014, p. 18).

A transformação da figura do Augusto em um imperador cristão por parte de Ambrósio começou, todavia, ainda em tempos de Graciano. Anterior ao texto laudatório dedicado a Teodósio pelo bispo milanês, percebo, no caso de Graciano, que a divinização do Augusto vivo, antes amparada pelas tradições greco-romanas, foi readaptada nos escritos ambrosianos. A manutenção, por parte de Ambrósio, do título "Augusto" e o acréscimo da santidade concedida pelo Deus cristão a Graciano mesclavam elementos tradicionais e inovações cristãs. Portanto, a divinização imperial continuou a ser um artifício essencial na caracterização do governante, destacado como um líder perfeito para os romanos e merecedor do culto imperial. Deste modo, comparto a afirmação 
de Bonamente: "conciliar a divinização com a santificação era um elemento central do modelo tradicional [cristão], aquele em que o imperador era chamado ao céu em razão da sua função institucional" (BONAMENTE, 2011, p. 345).

Já no início do De fide (I, Prologus, 2), Ambrósio sacralizou Graciano e elucidou que a fé nicena havia sido infundida no Augusto pelo próprio Deus. Elaboração que garantia ao governante sua áurea divina e a manutenção do culto imperial. Ao mesmo tempo, o bispo fazia de Deus o autor da fé nicena. Não o autor de todos cristianismos, noto, apenas daquela crença considerada verdadeira, explicada nos tratados ambrosianos e que enaltecia a Trindade Divina. Aqueles que, portanto, aprovavam as ideias do bispo seriam identificados como cristãos, sem se diferenciar como nicenos, pois, para Ambrósio, este era o único cristianismo, o verdadeiro; as demais crenças cristãs eram tratadas como heresias. Além disso, o público do bispo milanês identificava-se com a fé de Graciano e como súditos deste Augusto, uma vez que ele seria o governante ideal para proteger os romanos do perigo godo e para frear o fortalecimento de heresias. Aqui, várias identidades eram fortalecidas: um imperador santificado; um líder para os romanos; cristãos; e súditos.

Esta "santificação" de Graciano, estampada no Prólogo do livro I do tratado De fide, foi corroborada pelo título de "santo" (sanctus) oferecido ao imperador pelo bispo oito vezes ao longo desta obra e duas vezes em De Spiritu Sancto. O historiador Peter Brown (1993, p. 134) sustenta que Ambrósio fez da figura imperial um militans pro Deo que, no serviço ativo para o Deus cristão, servia de exemplo para os habitantes do Império. Ao nomear Graciano "santo", o bispo aplicou o poder do governante em prol de Deus e identificou o Augusto como um cristão-niceno, desejoso de aprender a respeito desta crença, e, por isso, um modelo a ser seguido.

Foi pela alcunha de "santo imperador" que Ambrósio chamou a atenção de Graciano para elucidar os princípios da Trindade protegida pela fé nicena: "Santo imperador, penso que ficou claro que o Senhor Jesus não é dessemelhante (dissimilem) ao Pai, nem pertencente ao tempo" (Amb., De fide, I, 14, 86). E insistiu: "Santo imperador, penso que, no livro anterior, deixamos claro que o Filho de Deus é eterno, semelhante ao Pai, gerado e não criado" (Amb., De fide, II, 1, 1). Ainda em tempo, no tratado De Spiritu Sancto, Ambrósio redigiu: "Recebas, santo imperador, outro exemplo válido sobre este assunto, ainda que já o conheças. [...] A profecia se dá não só por meio do Pai e do Filho, senão também por meio do Espírito Santo" (Amb., De Sp. San., II, 13, 143).

Estas três evocações ao "santo imperador" foram postas nos mesmos parágrafos de explicações sobre a Trindade Divina. Elaborações que vinculavam dois elementos basilares da fala/escrita ambrosiana: a Trindade Divina e a santidade imperial. A unidade da Trindade foi salientada por meio da negação da dessemelhança entre Pai e Filho e 
pela união entre Pai, Filho e Espírito Santo. E, em outro trecho, lá estavam novamente em destaque "unidade" e o "santo imperador": "Tenhas em conta, santo imperador [...] a onipotência é própria do Pai e do Filho, mas o Deus onipotente é uno, porque a unidade é característica da potestade" (Amb., De fide, II, 4, 36).

Tanto no tratado De fide como em De Spiritu Sancto, Graciano era o principal interlocutor do bispo: "Tenhas em conta, santo imperador" ou "Recebas, santo imperador". Entre outros exemplos, estas frases foram construídas tendo como vocativo "santo imperador". Evocava-se a atenção do Augusto. Graciano era, assim, aquele que ouvia e aprendia - apesar de já ter a fé infundida em si pelo próprio Deus, como o sacerdote esclarecera.

E para não restar dúvida de que Ambrósio tratava da fé formatada a partir do Concílio de Niceia, ele elucidou: "Compreendeste, santo imperador, que aqueles que afirmam tais coisas, são condenados com justiça. [...] A cruz estava representada nos trezentos bispos" (Amb., De fide, I, 18, 121). O autor afirmou que sua redação estava baseada no concílio que, sob o governo de Constantino, reuniu trezentos e dezoito bispos na cidade de Niceia no ano de 325. Ressalto que este esclarecimento também tem como vocativo "santo imperador", aquele que escutava as palavras episcopais e que deveria condenar "com justiça" aqueles que desconfiavam desta crença.

De acordo com as elaborações ambrosianas aqui analisadas, o "santo imperador", protegido por Deus, estava na terra para defender a Trindade Divina e aqueles que nela acreditavam. O Augusto louvado pelo bispo não era mais um governante para os romanos, mas, sim, um governante para os cristãos. Aqui retomo a argumentação de Escribano Paño (2009, p. 39), que percebe que, a partir do século IV, houve uma identificação da romanidade com o cristianismo e a consequente exclusão social daqueles que não compartilhavam desta crença. Tanto na legislação - como Escribano Paño aborda em seu estudo - como nos textos literários, dentre os quais incluo os tratados ambrosianos, a identificação entre cristianismo e a sociedade era evidente. $O$ bispo milanês fez de Graciano um santo líder, ideal para comandar o povo de Deus na terra. Uma identidade necessária para uma religião que ansiava ser reconhecida como ortodoxa.

Ao relacionar a santidade imperial e a Trindade Divina, o bispo conseguia legitimar a liderança imperial, garantindo ao governante sua natureza divina, e, ao mesmo tempo, validar o dogma niceno, visto que este estaria sendo apoiado e desejado por Graciano.

A partir da identificação de Graciano e de seus súditos com a fé nicena, Ambrósio contribuía para excluir das benesses sociopolíticas imperiais aqueles que não recebiam esta identificação. A estes restavam ser "ímpios" e sofrerem com a "perfídia de outros", conforme afiançou o bispo: 
Parece, santo imperador, que nossa exposição está cheia de piedade (pietatis), mas aos ímpios (impiis) não parece assim. (Amb., De fide, 1, 2, 27).

Santo imperador, não há dúvida que aqueles que padeceram com a perfídia dos outros (perfidiae alienae), vão encontrar em ti uma ajuda da fé católica (fidei catholicae) (Amb., De fide, II, 16, 139).

Estes excertos salientavam as oposições entre nicenos e não-nicenos. Diferenciações essenciais na construção da identidade nicena. Enquanto aqueles eram caracterizados como portadores da "piedade", estes seriam "ímpios" e adoeciam devido à perfídia. Observo que a identificação, aqui, era elaborada a partir de contraposições. Ambrósio definia sua exposição como "piedosa"; sendo "piedosos", então por identificação, aqueles que a seguiam. Esta construção discursiva nutria, mais uma vez, a noção de ortodoxia requerida pela crença nicena. A partir desta premissa, os demais indivíduos seriam valorados negativamente; seriam opostos, heréticos e, assim, excluídos da identidade e da ordem sociopolítica do Império desejada por Ambrósio.

Observo que uma identidade era - e ainda é - erigida a partir de critérios de alteridades, do olhar que define a si e exclui o outro. Alteridade que o historiador JeanPierre Vernant $(1988$, p. 12) reconhece ter sido utilizada entre os gregos. Foi a partir do critério de alteridade que Platão opôs "a categoria do mesmo à do outro em geral". Portanto, estudar a elaboração de discursos antigos - quer sejam gregos ou de seus herdeiros culturais, como os romanos - com base na alteridade não é nada anacrônico. Pensando sob este ponto de vista, noto que uma identidade é criada pari passu com uma diferenciação. No caso aqui estudado, observo que Ambrósio identificou a crença do Concílio de Niceia como piedosa, protegida por um "santo imperador" e católica, ou seja, universal, sendo assim, esta era a fé correta, ortodoxa. Em contrapartida, as crenças que negavam esta verdade elaborada pelo bispo, eram entendidas como heréticas. Com o olhar sobre o outro, sobre aquele que não era niceno, Ambrósio criou um discurso que identificou aquela crença que ele considerava verdadeira e, ao mesmo tempo, excluiu desta crença inúmeros romanos que discordavam de suas argumentações.

O jurista Jean Gaudemet afirma que, para Ambrósio, seu cristianismo era universal, assim como era universal o Império romano. Segundo Gaudemet (1958, p. 52), em suas obras, Ambrósio fez paralelismos entre a universalidade imperial e a universalidade da fé. Conforme as elaborações ambrosianas, portanto, o poder de império universal deveria proteger, em todas as terras do Império, os cristãos criados por um Deus Uno e Trino. Seria lógico que o detentor deste poder de império, neste caso Graciano, ganhasse a sacralidade através do próprio Deus, como afirmou Ambrósio. Cabia, portanto, ao sacerdote milanês ressaltar esta natureza santa de Graciano. 
Noto, ainda, que no último excerto trazido, Ambrósio anunciou que os "ímpios", portanto excluídos da sociedade desejada pelo bispo, encontrariam no "santo imperador [...] uma ajuda da fé católica". Uma elaboração que reforçava a defesa de tal fé por Graciano e que, servindo como exemplo, o Augusto conseguiria exterminar a "perfídia dos outros". Ressalto aqui os ideais de universalidade do poder de império e da universalidade da crença nicena: um único imperador em suas terras; uma única crença. Paralelamente, Ambrósio reforçava a noção de que Graciano governava para os cristãos.

Recordo que estas construções discursivas amparavam uma religião que pouco a pouco se construiu como ortodoxa e universal. Todavia, este foi um processo longo. E por mais que muitos discursos cantem "a vitória definitiva do niceísmo no Império romano", aos moldes da clássica obra de Edward Gibbon, esta religião sempre concorreu com outros cristianismos e com outras religiões.

Reforço, entretanto, o papel de Ambrósio na identificação e na imposição de limites do que era "ser cristão", sempre da perspectiva do credo niceno. Neste caminho, o bispo encontrou em Graciano um governante que Ihe forneceu espaços públicos importantes para a defesa da fé nicena. Simultaneamente, a fim de incrementar seus vínculos com o poder imperial e fortalecer a imagem deste Augusto que o apoiava, o bispo fez deste governante um "santo imperador".

\section{Considerações finais}

Em um contexto de fortalecimento do cristianismo niceno, ao longo do século IV, Ambrósio encontrou nas solicitações de Graciano significativas oportunidades de esclarecer sua fé e anunciá-la como única e verdadeira. Mais do que a defesa cega de uma religião, este ato era uma ação sociopolítica que garantia espaços importantes na hierarquia eclesiástica que se formatava e requeria lugar dentro da elite romana. A voz ativa de Ambrósio em Milão, por exemplo, garantiu acesso a cátedras episcopais a muitos de seus indicados no norte da Itália.

Adotando as ideias que pululavam no ambiente sociopolítico da época ou/e no próprio Edito de Tessalônica, o fato é que os termos "católico" e "herético" foram amplamente utilizados nos escritos ambrosianos com o objetivo de requerer a ortodoxia para o niceísmo e refutar o arianismo, coberto de adjetivos negativos. Uma construção retórica aprovada por Graciano, visto que o imperador solicitou ao bispo que ampliasse a obra De fide e esclarecesse a natureza do Espírito Santo - pedido que impulsionou a escrita de outros três livros do De fide e a redação do De Spiritu Sancto. 
O fato de Ambrósio ter seus lugares de atuação como bispo e defensor de uma crença religiosa garantidos por Graciano o destacava diante da comunidade milanesa. É compreensível que, ao longo de seus tratados De fide e De Spiritu Sancto, Ambrósio tenha edificado para Graciano a imagem de um imperador preocupado com os assuntos de guerra e com os assuntos religiosos. Tal idealização fazia do Augusto um governante indispensável para os romanos e sua utilidade púbica era, então, garantida. Trato aqui de discursos, de idealizações que alimentavam a teoria política de Graciano e ajudavam a legitimar seu poder, ao mesmo tempo que nutriam um discurso favorável ao niceísmo.

É fato que Ambrósio realçou a divindade própria da figura imperial, mas com Graciano, o bispo fez do imperador um "santo" e o governante correto para proteger os cristãos das heresias que pululavam naquele cenário e geravam cristianismos plurais. Ao longo destes dois tratados, Ambrósio traçou um vínculo entre o Augusto, seus súditos e a religião nicena, criando uma aliança retórica entre o niceísmo e o imperador. Por isso, mais do que de obras doutrinárias, estes tratados também foram instrumentos sociopolíticos que ampararam a utilidade pública de Graciano frente à comunidade nicena milanesa e ajudaram a corroborar a ortodoxia desta crença.

\section{Agradecimentos}

Este artigo é fruto de uma conferência realizada no Instituto de Letras Clássicas da Universidade de Coimbra, em fevereiro de 2019. Agradeço ao Prof. Dr. José Luís Brandão (Universidade de Coimbra), à Profa. Dra. Cláudia Teixeira (Universidade de Évora), às alunas e aos alunos presentes naquela ocasião pelo excelente debate a respeito de "Identidades Romanas". Agradeço também à Fundação de Amparo à Pesquisa do Estado de São Paulo (Fapesp), pelo financiamento de minha pesquisa de pós-doutorado no Brasil (processo 2016/20942-9) e no Exterior (BEPE - Espanha processo 2017/26939-2; BEPE Itália processo 2018/03187-8).

\section{Referências}

\section{Documentação textual}

AMBRÓSIO. El Espíritu Santo. Introducción, traducción y notas de S. J. Carmelo Granado. Madrid: Ciudad Nueva, 1998. 
AMBRÓSIO. De Spiritu Sancto: Texto latino disponível em: <http://www. documentacatholicaomnia.eu/04z/z_0339-0397_Ambrosius_De_Spiritu_Sancto_ Libri_Tres_MLT.pdf.html>. Acesso em: 26 set. 2018.

AMBRÓSIO. De fide: sobre la fe. Introducción, traducción y notas de Secundino García. Madrid: Ciudad Nueva, 2009.

AMBRÓSIO. De fide. Texto latino disponível em: < http://www.documentacatholicaomnia. eu/02m/0339-0397,_Ambrosius,_De_Fide_Ad_Gratianum_Augustum_Libri_ Quinque,_MLT.pdf>. Acesso em: 26 set. 2018.

AMMIANUS MARCELLINUS. Historia. Edición de Maria Luisa Harto Trujillo. Madrid: Akal, 2002.

AMMIANUS MARCELLINUS. Res gestae. English translation by John C. Rolfe. London: William Heinemmann, 1935.

IMPERATORIS THEODOSII CODEX. Disponível em: <http://ancientrome.ru/ius/library/ codex/theod/tituli.htm>. Acesso em: 15 dez. 2018.

PLATÃO. A República: livros I, VII. Tradução de Pietro Nassatti. São Paulo: Martin Claret, 2009.

PLATÃO. Diálogos II: Gorgias, Menéxeno, Eutidemo, Menón, Crátilo. Traducciones, Introducciones y notas por J. Calonge Ruiz, Acosta Méndez y F. J. Olivieri. Madrid: Gredos, 1992.

\section{Obras de apoio}

BAUMAN, Z. Identidade: entrevista a Benedetto Vecchi. Rio de Janeiro: Jorge Zahar, 2005. BONAMENTE, G. Dall'imperatore divinizzato all'imperadote santo. In: BROWN, P.; TESTA, R. L. (Ed.). Pagans and Christians in the Roman Empire: the breaking of a dialogue (IV - V Century A.D.). Zürich: Lit Verlag, 2011. p. 339-370.

BONAMENTE, G. Teodosio el grande e la fine dell'apoteosi imperiale. In: ESCRIBANO PAÑO, M. V.; TESTA, R. L. (Ed.). Política, religión y legislación en el Imperio Romano (ss. IV y V d.C.). Bari: Edipuglia, 2014, p. 17-36.

BROWN, P. Aspects of the Christianisation of the Roman world. Cambridge: Cambridge University, 1993.

CAMERON, A. Christianity and the rhetoric of Empire: the development of Christian discourse. Oxford: Universtiy of California Press, 1991.

ESCRIBANO PAÑO, M. V. Emperadores y leyes en época teodosiana (Codex Theodosianus 16, 5, De Haereticis). In: ESCRIBANO PAÑO, M. V.; TESTA, R. L (Ed.). Política, religión y legislación en el Imperio Romano (ss. IV y V d.C.). Bari: Edipuglia, 2014, p. 61-82. 
ESCRIBANO PAÑO, M. V. The social exclusion of herectics in Codex Theodosianus XVI. In: Droit, religion et sociéte dans le Code Théodosien. Troisièmes Journées d'Etude sur le Code Théodosien, Université de Nuechâtel, 15-17 février 2007. Genéve: Librairie Droz, 2009, p. 39-66.

GAUDEMET, J. L'Église dans L'Empire Roman (IV - V siècles). Paris: Sirey, 1958.

HALSALL, G. Las migraciones bárbaras y el Occidente romano, 376-568. València: Universitat de València, 2012.

HUMFRESS, C. Ortodoxy and the courts in Late Antiquity. New York: Oxford University Press, 2007.

MCLYNN, N. B. Ambrose of Milan: Church and court in a Christian capital. Berkeley: University of California Press, 1994.

MCLYNN, N. B. Christian politics and religious culture in Late Antiquity. Farnham: Ashgate, 2009.

PERKINS, J. Roman imperial identities in the Early Christian Era. London: Routledge, 2009.

TESTA, R. L. La politica religiosa di Teodosio I. Atti della Accademia Nazionale dei Lincei. Classe di Scienze Morali, Storiche e Filologiche, s. IX, v. VII, f. 2, p. 323-361, 1996.

TESTA, R. L. Legislazione imperiale e reazione pagana: i limiti del conflitto. In: BROWN, P.; TESTA, R. L. (Ed.). Pagans and Christians in the Roman Empire: the breaking of a dialogue (IV - V Century A.D.). Zürich: Lit Verlag, 2011. p. 467-491.

VERNANT, J-P. A morte nos olhos: figuração do outro na Grécia Antiga - Ártemis, Gorgó. Rio de Janeiro: Jorge Zahar, 1988.

WALLERSTEIN, I. M. O universalismo europeu: a retórica do poder. São Paulo: Boitempo, 2007. 